\title{
Insights into the speleogenesis of Ejulve cave (Iberian Range, NE Spain): quaternary hydrothermal karstification?
}

\author{
Carlos Pérez-Mejías ${ }^{1,2}\left(\right.$ C $\cdot$ Carlos Sancho ${ }^{2} \cdot$ Fernando Gázquez $^{3} \cdot$ Ana Moreno $^{1} \cdot$ Miguel Bartolomé $^{1,4}$. \\ M. Cinta Osácar ${ }^{2} \cdot$ Hai Cheng ${ }^{5,6}$
}

Received: 13 December 2018 / Accepted: 17 May 2019 / Published online: 11 June 2019

(c) Universidad Complutense de Madrid 2019

\begin{abstract}
We provide first insights into the speleogenesis of Ejulve cave (Teruel province, Iberian Range, NE Spain) by studying cave morphologies and cave deposits, combined with regional geomorphological and hydrothermal observations. Three main hydrogeomorphic evolutionary stages can be distinguised to explain the origin and evolution of the Ejulve endokarstic system. Cave pattern and cave solutional features (calcite vein fillings, tubes with rising ceiling cupolas, pendants and cusps, spongework and micro-corrosion features) suggest that the cave generated in a phreatic environment by ascending water. Cave morphologies and regional hydrothermal springs in this region suggest, but not prove, the involvement of thermal waters and related convection and condensation-corrosion mechanisms in the origin of the cave. Subsequently, the cave underwent a change to epigenic conditions driven by denudation, as a result of regional uplift. Once the karstic system was exhumated, carbonate speleothems formed in a vadose environment. Mineralogical, petrographic, isotopic and chronological (U-series dating) analyses of carbonate speleothems (i.e. stalagmites, flowstones, botryoids, spars, acicular crystals and farmed carbonate) are provided. Calcite, high-Mg calcite and aragonite are the most common minerals, whereas columnar, dendritic, micrite, mosaics and fans are the main fabrics. Mean $\delta^{18} \mathrm{O}$ values of $-7.3 \%$ and $\delta^{13} \mathrm{C}$ values of $-9.1 \%$ indicate carbonate precipitation from meteoric waters without a hydrothermal origin. Carbonate deposits formed at least since $650 \mathrm{ka} \mathrm{BP}$. Our study suggests that hydrothermal fluid flow may explain, although the evidences are not fully conclusive, the speleogenesis of this cave.
\end{abstract}

Keywords Speleogenesis $\cdot$ Cave morphologies $\cdot$ Carbonate speleothems $\cdot$ Meteoric regime $\cdot$ Iberian range

\section{Resumen}

Se aportan las primeras evidencias sobre la espeleogénesis de Ejulve (Teruel, Cordillera Ibérica, NE España) a través del estudio de morfologías y depósitos, junto a geomorfología regional y observaciones hidrotermales. Así, se pueden establecer tres etapas en la evolución hidro-geomórfica para explicar el origen y evolución del sistema endokárstico de Ejulve. El patrón de la cueva y las morfologías (venas de calcita, tubos con cúpulas ascendentes, pendants y cusps, spongework y rasgos de microcorrosión) sugieren que la cueva se ha generado en ambiente freático debido a aguas ascendentes. Las morfologías de la cueva y el hidrotermalismo regional en la región sugieren, aunque no prueban, la implicación de aguas termales y mecanismos de convección y condensación-corrosión en el origen de la cueva. Posteriormente, la cueva experimentó un

Deceased: Carlos Sancho.

Carlos Pérez-Mejías

cperez@ipe.csic.es

1 Department of Geoenvironmental Processes and Global Change, Pyrenean Institute of Ecology-CSIC, Avenida Montañana 1005, 50059 Saragossa, Spain

2 Earth Sciences Department, University of Zaragoza, Pedro Cerbuna 12, 50009 Saragossa, Spain

3 Department of Biology and Geology, Universidad de Almería, Carretera de Sacramento s.n, La Cañada de San Urbano, 04120 Almería, Spain

4 Geology Department. Museo Nacional de Ciencias Naturales, C/José Gutiérrez Abascal 2, 28006 Madrid, Spain

5 Institute of Global Environmental Change, Xi'an Jiaotong University, Xi' an 710049, China

6 State Key Laboratory of Loess and Quaternary Geology, Institute of Earth Environment, Chinese Academy of Sciences, Xi' an 710075, China 
cambio a condiciones epigénicas conducido por un proceso de denudación, como resultado de la elevación regional. Una vez que el sistema kárstico ha sido exhumado, se formaron los espeleotemas en un ambiente vadoso. Asimismo, se ofrecen análisis mineralógicos, petrográficos, isotópicos y cronológicos (series de uranio) en diferentes espeleotemas (estalagmitas, coladas, botroides, spar, cristales aciculares y carbonato precipitado). Las mineralogías más comunes son calcita, calcita con alto contenido en $\mathrm{Mg}$ y aragonito, mientras que las fábricas más comunes son columnar, dendrítica, micrítica, mosaicos y abanicos. Los valores medios de $\delta^{18} \mathrm{O}$ son de $-7.3 \%$ y $\delta^{13} \mathrm{C}$ de $-9.1 \%$, indicando precipitación de carbonato procedente de aguas meteóricas sin un origen hidrotermal. Los depósitos se formaron al menos desde hace $650 \mathrm{ka}$. Este estudio sugiere que fluidos hidrotermales pueden explicar, aunque las evidencias no son totalmente conclusivas, la espeleogénesis de esta cueva.

Palabras clave espeleogénesis $\cdot$ morfologías $\cdot$ espeleotemas $\cdot$ régimen meteórico $\cdot$ Cordillera Ibérica

\section{Introduction}

Quaternary karst dynamics in the southeastern sector of the Iberian Range (NE Iberian Peninsula) derived large fields of exokarstic landforms, mainly dolines and poljes, superimposed on the extensive Pliocene Main Erosive Surface of the Iberian Range (Peña et al. 1984), mostly developed on Mesozoic limestone bedrock (Gutiérrez and Peña 1994). Also, the external morphosedimentary response to Quaternary karst dynamics, as evidenced by fluvial tufa records, is a well-known landscape feature on a regional scale (Sancho et al. 2015). In contrast to this intensive exokarstic activity, only very scarce endokarstic features, including caves, are known in this region (Castellano et al. 2015). Changing regional landscape related to a Miocene-Pliocene-Quaternary extensional regime (Simón et al. 2002; Gutiérrez et al. 2008) and fluvial incision did not promote the formation of extensive endokarstic systems.

In this geomorphological karstic setting, Ejulve cave (also known as El Recuenco Cave) in the southeastern Iberian Range stand out, because of its comparatively large size ( $\sim 800 \mathrm{~m}$ long). In general, all caves in this region are characterized by small sizes and a high vertical/horizontal development index ratio. Some of them (e.g. Molinos and Ejulve caves) were selected for regional paleoclimate studies using stalagmite records (Moreno et al. 2017; Pérez-Mejías et al. 2017). Nevertheless, the regional morphogenesis of the endokarst in this sector of the Iberian Range remains underinvestigated. Speleogenesis deals with the origin and development of cave systems (Klimchouk et al. 2000; Ford and Williams 2007) and is based on cave morphologies as well as the analysis of speleothem deposits.

Previous speleogenetic investigations have been conducted on cave systems in the main calcareous mountains ranges of the northern Iberia (Cantabrian Mountains, Pyrenees and northwestern Iberian Range) (e.g. Ortega et al. 2013; Aranburu et al. 2015; Ballesteros et al. 2015; Bartolomé et al. 2015; Dodero et al. 2015), southern Iberia (Betic Mountain Range) (Durán et al. 1993; Calaforra and Berrocal 2008; Gázquez et al. 2016, 2017) and the Balearic Islands
(Gràcia et al. 2011; Ginés et al. 2017). Most endokarstic systems correspond to meteoric caves even though some of them in Betic Mountain Range and Balearic Islands are associated to hydrothermal activity (Gázquez et al. 2016, 2017; Ginés et al. 2017), according the classification of karst solution caves by Ford and Williams (2007).

This study aims at providing first insights into the speleogenesis (processes and timing) of Ejulve cave by (1) the study of cave morphologies, (2) the analysis of carbonate speleothems, including mineralogical, petrographic, isotopic and chronological characteristics, and (3) framing of the cave in the regional geomorphological and hydrogeological context.

\section{Study area}

Ejulve cave $\left(40^{\circ} 45^{\prime} 34^{\prime \prime} \mathrm{N}\right.$; $0^{\circ} 35^{\prime} 07^{\prime \prime} \mathrm{W}$; $1240 \mathrm{~m}$ a.s.l.) is a cavity located in the southeastern sector (Maestrazgo Unit) of the Iberian Range (Teruel province) (Fig. 1a), a mountain range in northeastern Iberia, representing the uplift and compressive inversion of a Mesozoic extensional basin (Álvaro et al. 1979; Simón et al. 2002; Sopeña 2004). Mesozoic sedimentary sequences are grouped in two evolutionary cycles, Late Permian-Middle Jurassic and Late Jurassic-Late Cretaceous (Simón et al. 2002; Sopeña 2004). Subsequent convergence of the Iberian and European plates caused the switch from extensional to compressional tectonics. Consequently, Mesozoic sedimentary rocks are affected by NW-SE and NE-SW trending folds, thrusts and faults (Simón et al. 2002) (Fig. 2a). Ejulve cave is developed in Upper Cretaceous dolomitic limestones and dolostones of the Mosqueruela Fm (Canérot 1982) which is 90 m thick. Jurassic rocks including impermeable marls (30 m thick) are thrusted above the dolomitic Upper Cretaceous sequence (Fig. 2b). Oligocene and Miocene syn- and post-orogenic conglomerates, sandstones and claystones top this Mesozoic sequence. Mesozoic and Oligocene deposits are affected by the Portalrubio-Vandellós thrust system (Guimerà 1988; Liesa 1998; Simón et al. 2002). 

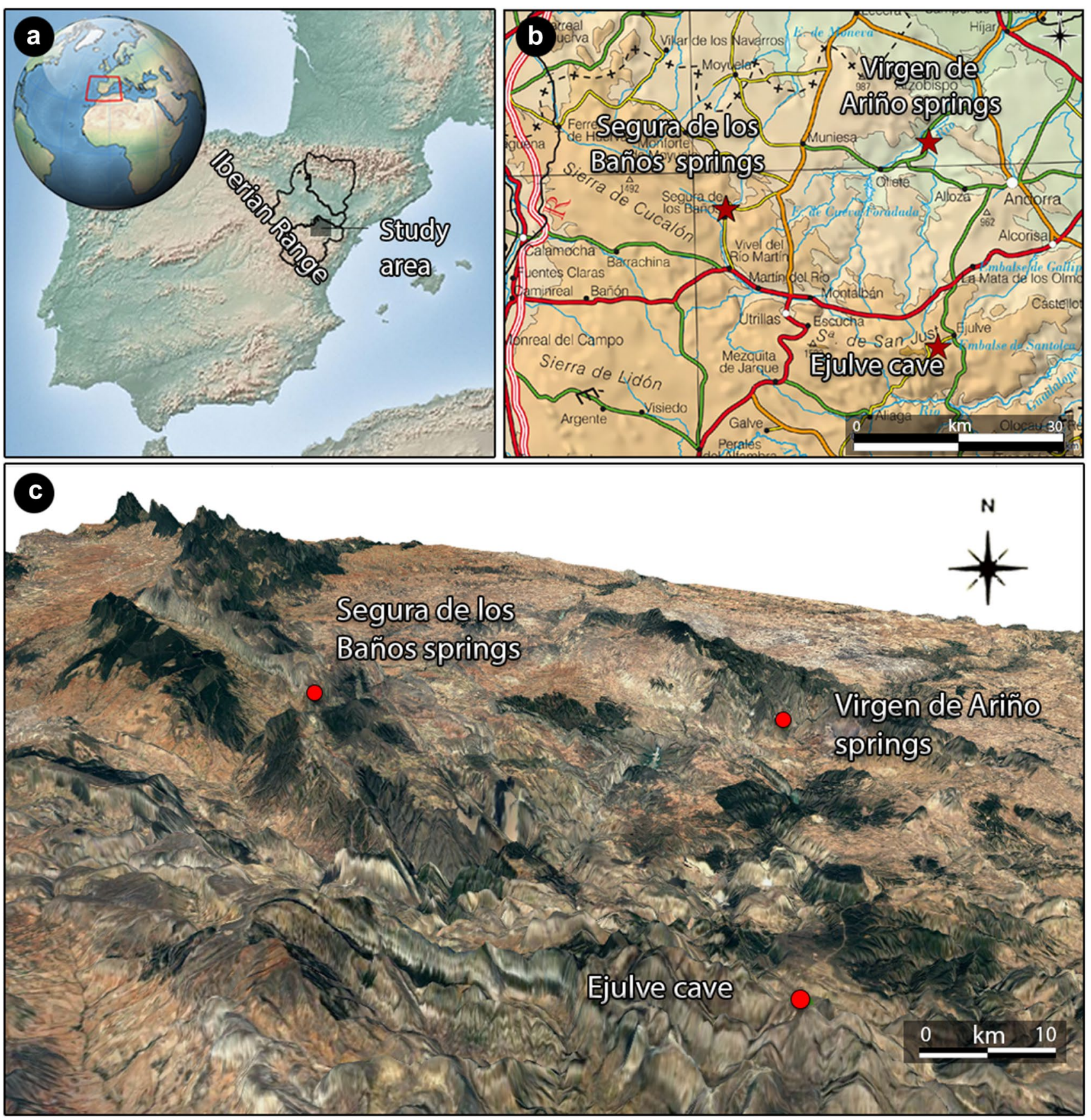

Fig. 1 a Study area. b, c Location of the Ejulve cave, Ariño and Baños de Segura thermal springs are also shown

The landscape in this area is relatively flat, dominated by extensive high-altitude platforms and planation surfaces (1000-1600 m a.s.1.). At a regional scale, the occurrence of the extensive Main Erosive Surface formed during the UpperMiocene and Pliocene is remarkable (Peña et al. 1984; Gutiérrez and Peña 1994). In addition, the landscape appears partitioned by Mio-Pliocene-Quaternary, multi-story tectonic grabens related to an extensional tectonic regime guided by the Valencia trough rifting (Simón et al. 2002; Gutiérrez et al.
2008), followed by fluvial incision (Scotti et al. 2014). The Ejulve area belongs to the Sant Just-Castellote mountainous unit, dominated by remnants of planation surfaces and structural landforms related to the incision of the drainage network guided by the Guadalope River (Peña et al. 1984). The cave's bedrock is affected by intense denudation processes (Fig. 2c). In fact, geomorphological analyses revealed the presence of a gently sloping planation surface from 1300 to $1100 \mathrm{~m}$, extending from the foothills of Majalinos Mountain to the north of 

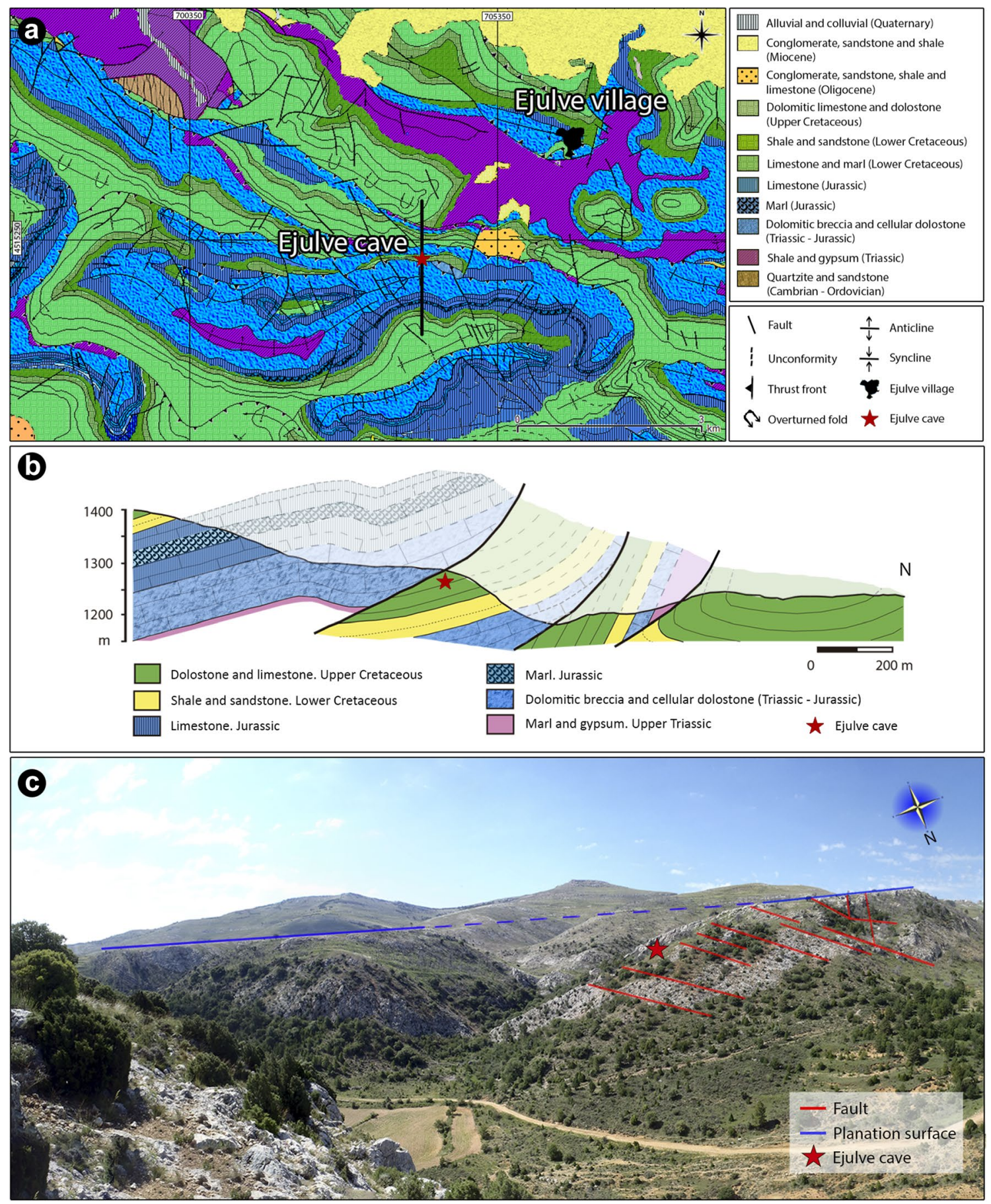

Fig. 2 Geological setting of Ejulve cave. Geological map (a), cross section (b) and main geological and geomorphological features (c)

Ejulve village. Pailhé (1984) interpreted this sloping surface as a piedmont planation, while Peña et al. (1984) and Simón (1984) suggested that it corresponds to the deformed Main Erosive Surface of the Iberian Range. The deformation of this planation surface is guided by postorogenic regional uplift (Giachetta et al. 2015).
The climate in the study area is Mediterranean with strong continentality and high seasonal contrast. Mean annual temperature is $8.5^{\circ} \mathrm{C}$ and mean annual precipitation is ca. $431 \mathrm{~mm}$, occurring between fall and spring. This temperature, recorded at the Majalinos weather station (located at $1601 \mathrm{~m} . a . s .1$. and $2 \mathrm{~km}$ far from the cave) is lower than the mean temperature of the cave $\left(11.3^{\circ} \mathrm{C}\right)$ 
during the period 2013-2016 (Pérez-Mejías et al. 2018). Soils are scarce and poorly developed, and support a degraded vegetation cover dominated by diverse heliophytic shrubs, holm and semi-deciduous oaks (Angosto and Latorre 2000).

\section{Materials and methods}

\subsection{Survey and sampling}

A detailed cave recognition was carried out using the cave topographic maps produced by Gisbert and Carvajal (1993) and Castellano et al. (2015). Some cave morphologies, different types of speleothems, major fault planes and large collapse breccias are elements identified in the cave. Morphological features including cave geometry and solutional features were identified and described at different scales following criteria by Ford and Williams (2007). In order to evaluate the role of the faults on the cave geometry, a total of 31 major fractures were measured and represented in a rose diagram using Stereonet software (Allmendinger et al. 2011; Cardozo and Allmendinger 2013). Several samples were collected and identified in Table 1, as follows. Carbonate blades projecting from the cave wall as boxwork were sampled (ID\#1-10 in Table 1). Additionally, carbonate speleothems including stalagmites (ART and HOR) and farmed carbonate (ID\#11-25), flowstones (ID\#26-36), botryoidal deposits (ID\#37-44), carbonate spar (ID\#45-50) and acicular crystals (ID\#51-57) were collected (Table 1). Finally, the dolomitic host rock (ID\#58-66) was also sampled. Details of samples and subsamples are reported in Table 1.

\subsection{Analytical techniques}

Powdered subsamples for X-ray diffraction (XRD), stable isotope analysis and U-Th dating were retrieved using a microdrill. The semiquantitative mineralogical composition was determined by XRD using the DIFFRACplus evaluation package. The analyses were performed at the Jaume Almera Institute (ICTJA-CSIC, Barcelona) with a Bruker AXS D5005 using a theta-2theta geometry, with a $\mathrm{Cu}$ X-ray tube operating at up to $2.2 \mathrm{~kW}$. A total of 56 samples were analyzed for their stable isotope composition $\left(\delta^{18} \mathrm{O}\right.$ and $\left.\delta^{13} \mathrm{C}\right)$ at the University of Barcelona (Scientific-Technical Services) using a Finnigan-MAT 252 mass spectrometer coupled to a Kiel Carbonate Device I. Samples were heated 4 min up to $70{ }^{\circ} \mathrm{C}$, therefore, the isotopic composition corresponds to bulk carbonates. Standards were run every 6 samples with a reproducibility better than $0.03 \%$ for $\delta^{13} \mathrm{C}$ and $0.06 \%$ 。 for $\delta^{18} \mathrm{O}$. Isotope values are reported as $\%$ with respect to the V-PDB (Vienna-Pee Dee Belemnite) standard. U-Th analyses (6 samples) were performed using a MC-ICP-MS (Thermo-Finnigan Neptune) at Xi' an Jiaotong University (China) following the methodology described in Cheng et al. (2013). Also, a selection of carbonate samples was microscopically studied by thin sections, some of those were red stained for the identification of dolomite. The fabrics were described according the terminology of Frisia et al. (2000), Frisia and Borsato (2010) and Frisia (2015).

\section{Results}

\subsection{Cave morphology}

\subsubsection{Cave pattern}

Ejulve cave is located very close to the current topographic surface and the uppermost ceiling, near the entrance, is overlain only by around $10 \mathrm{~m}$ of carbonate bedrock. The cave is composed of $794 \mathrm{~m}$ of galleries, reaching a maximum depth of $55 \mathrm{~m}$ (data from Castellano et al. 2015). The galleries display a maze network of irregular chambers interconnected by intricate passages. The three-dimensional pattern shows dominant NW-SE and NE-SW trends forming an angular grid of connected passages (Fig. 3a) controlled by major faults. The dominant fractures run NW-SE, while secondary fractures are NE-SW and W-E oriented (Fig. 3a, b). The fracture network is complemented with nearly horizontal faults (Fig. 3b) controlling the shape and size of some chambers. The dimensions (height $\times$ length $\times$ width) of the two largest chambers are $31 \times 16 \times 9 \mathrm{~m}$ and $15 \times 23 \times 10 \mathrm{~m}$ according to Gisbert and Carvajal (1993). The initial cave size was subsequently modified due to collapse processes guided by faults as evidenced by large blocks detached from the ceiling and accumulated on the floor of the rooms. Talus deposits related to cataclastic fault breccias have also been identified in chambers of the lower levels of the cave.

\subsubsection{Cave solutional features}

In the central areas of the cave, some vertical tubes several meters long with decimetric subcircular sections have been identified on chamber ceilings, connecting different nearby chambers (Fig. 4b). Occasionally, these tubes display a succession of small ceiling cupolas. Other remarkable morphologies common in this cave are pendants and cusps projected downwards from chamber ceilings. The shapes of bedrock projections, decimetric-to-metric in scale, vary from irregular and rounded (pendants) (Fig. 4c, d) to pointed angular (cusps) (Fig. 4e). The surface of the cusps is normally coated by carbonate speleothems. Among the dissolution morphologies identified in Ejulve cave, spongework stands out. It consists of irregular 


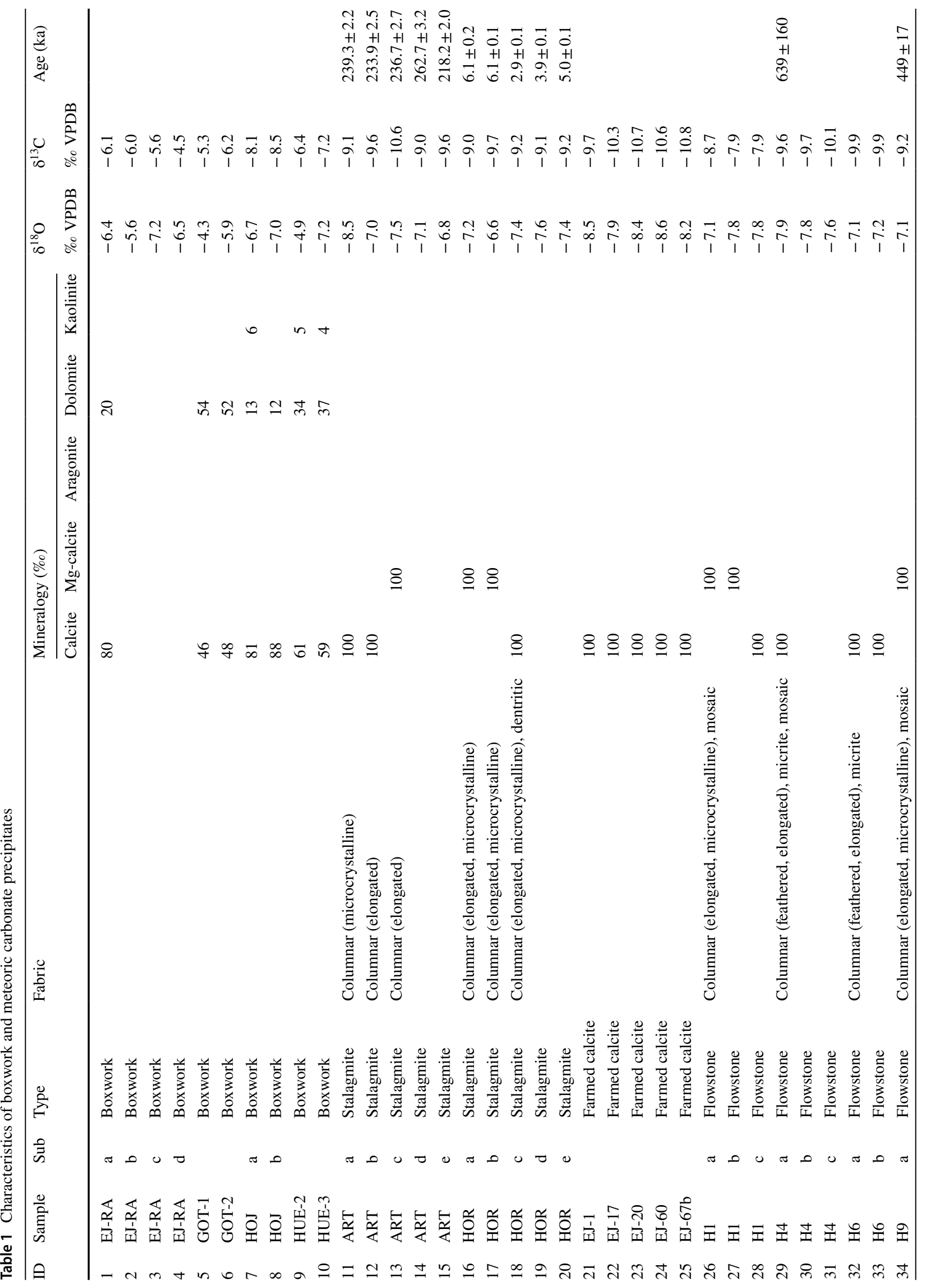




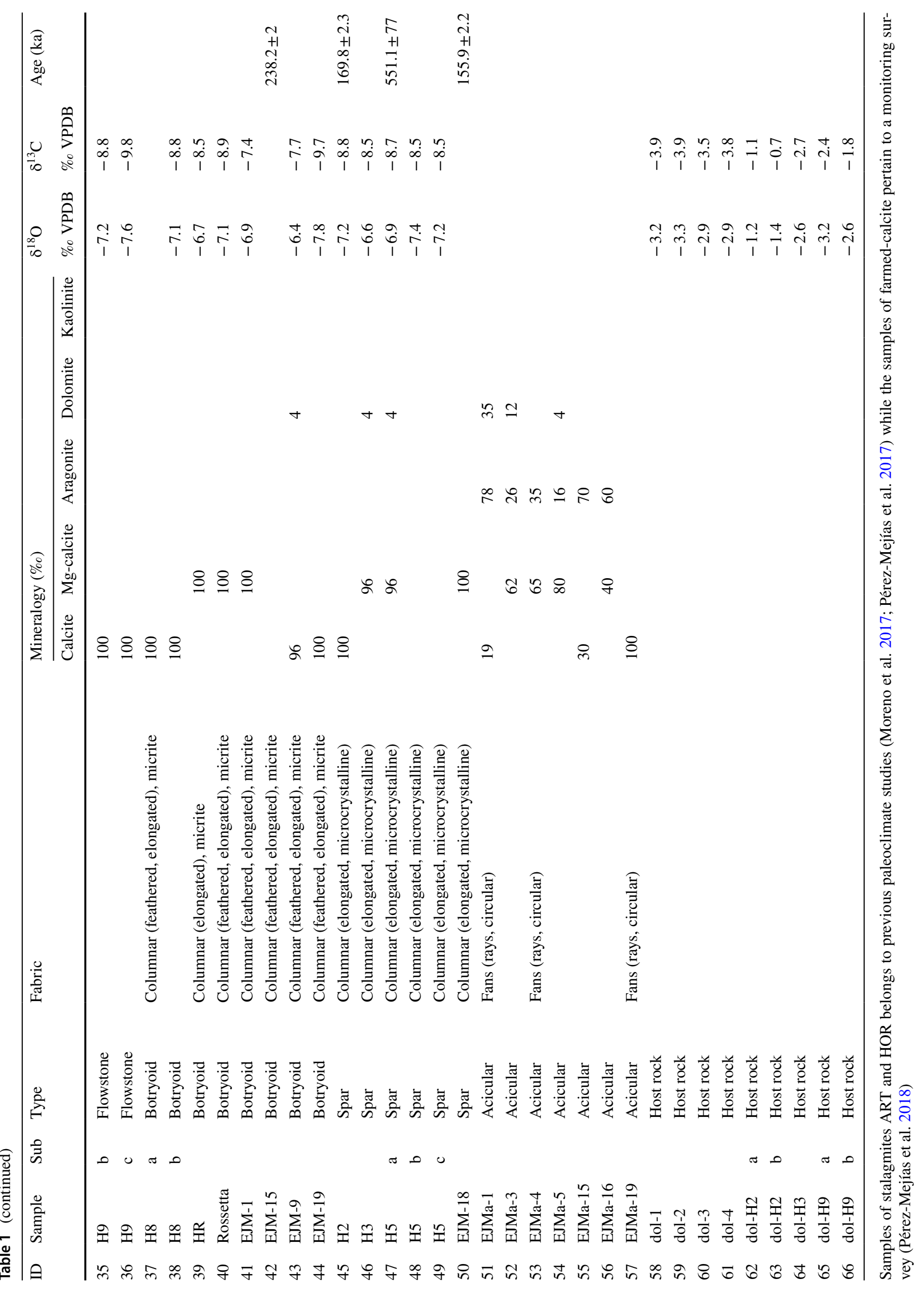




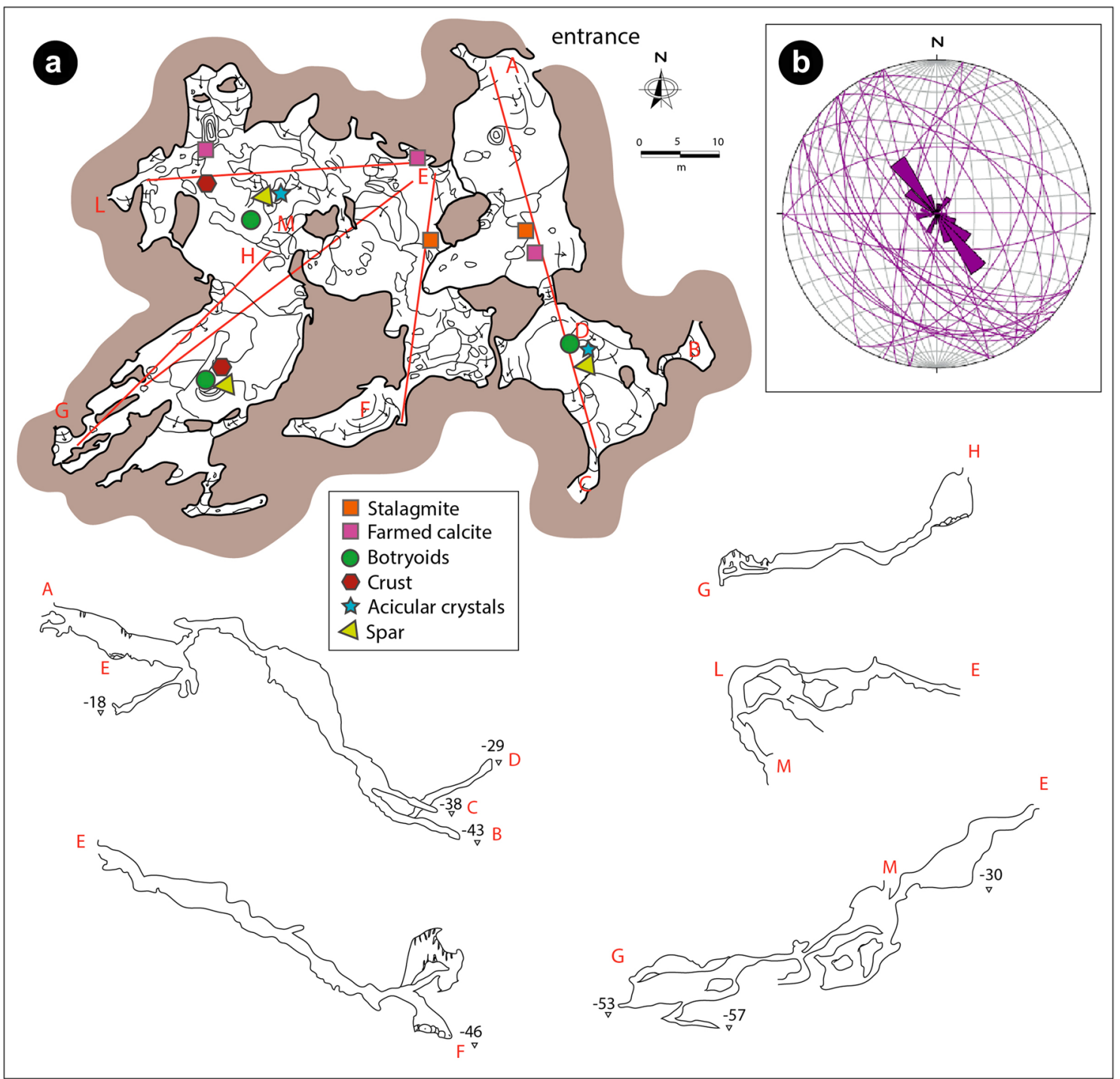

Fig. 3 Ejulve cave plan view and selected cave cross sections. The distribution of speleothems is also shown (a). Diagram of fault orientations (b)

decimetric frameworks formed in the dolomitic bedrock that are composed by a cluster of irregular interconnected voids (Fig. 4f). In addition, rare bubble trails and pockets are also present. Finally, microcorrosion features (rills) affecting the bedrock surface were commonly observed in polished slabs and thick sections, usually covered by carbonate speleothems (Fig. 4g). On the other hand, circular-elliptical and vertically elongated passage crosssections and scallops are absent in Ejulve cave.

\subsection{Boxwork}

Bedrock exposed in passages and chambers shows boxwork (Palmer 1991) constituting a centimetric-to-decimetric network of mineral blades projected from bedrock surfaces (Fig. 4a) widely distributed throughout Ejulve cave. The blades are composed of calcite-dolomite crystals and kaolinite, with pores lined with calcite and dolomite crystals (Table 1). Texturally, a wide-open fabric made of micro-blades and large pores has been identified (Fig. 5a). The average $\delta^{18} \mathrm{O}$ value of the analyzed carbonates (see mineralogical composition in Table 1) is $-6.4 \%$, ranging from -5.6 to $-7.2 \%$. The average $\delta^{13} \mathrm{C}$ value of the analyzed carbonates is $-5.6 \%$, ranging from -4.5 to $-6.1 \%$ (Table 1; Fig. 6).

\subsection{Carbonate precipitates}

Ejulve cave is moderately decorated with speleothems (Fig. 7a). Stalagmites, stalactites (Fig. 7a), curtains and 
Fig. 4 Boxwork (a). Cave solutional features: tubes with rising ceiling cupolas -view from above- (b), pendants (c, d), cusps coated with botryoidal carbonate deposits (e), spongework (f), and microcorrosion features on dolomitic bedrock lined with botryoidal laminated carbonate $(\mathbf{g})$
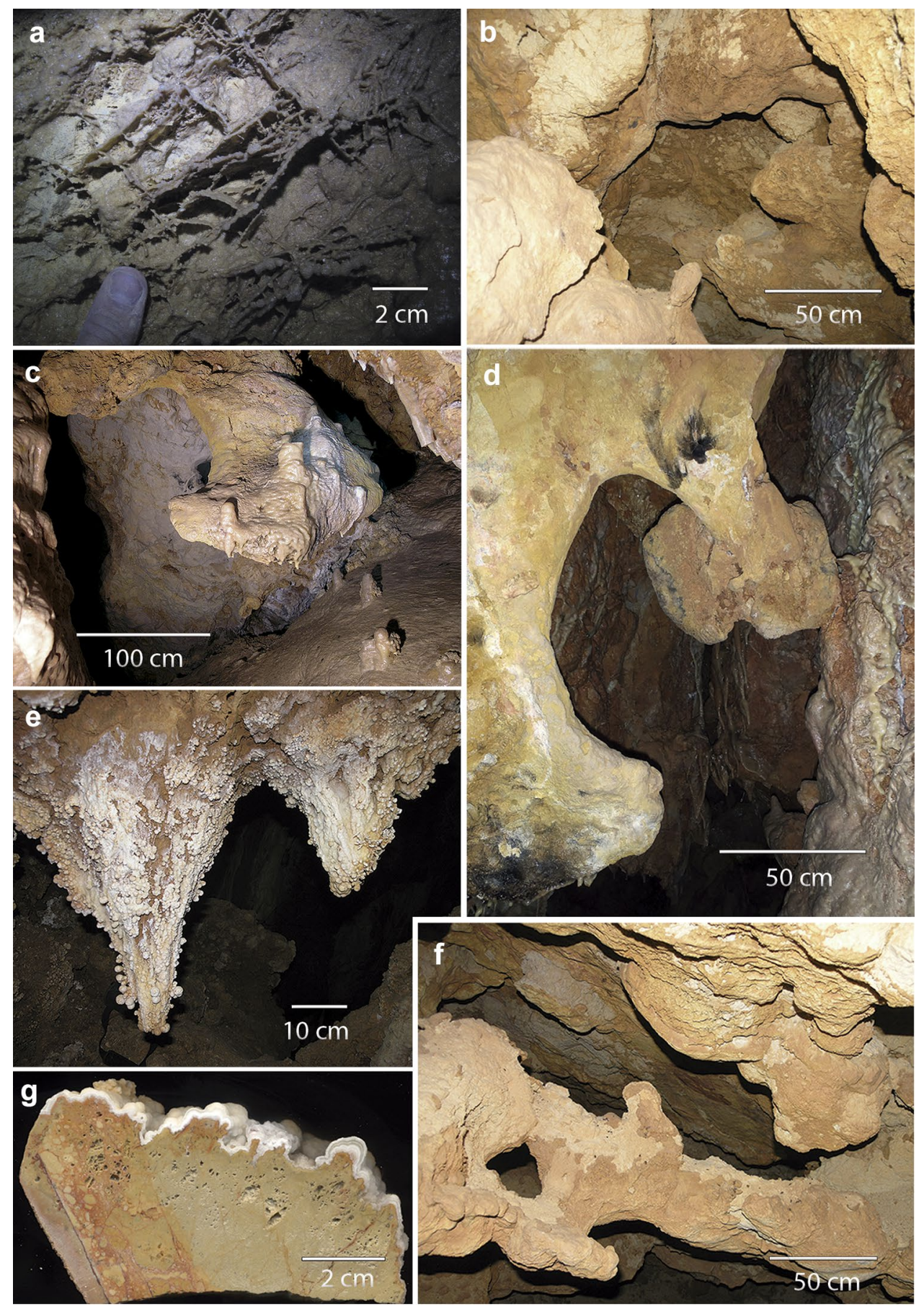

flowstones are frequent in the upper chambers and galleries of the cave. Several stages of stalagmite growth have been identified: MIS 8 to MIS 7e (stalagmite ART) (Pérez-Mejías et al. 2017), MIS 5 to MIS 3, and Holocene (stalagmite HOR) (Moreno et al. 2017). Stalagmites are made of calcite and high-Mg calcite (Table 1), displaying a wide variety of columnar (short, elongated columnar, microcrystalline, radiaxial and fascicular types) (Fig. 5b) and dendritic fabrics. Samples of stalagmites ART (PérezMejías et al. 2017) and HOR (Moreno et al. 2017) exhibit mean $\delta^{18} \mathrm{O}$ values of $-7.4 \%$ and $-7.2 \%$ for ART and HOR, respectively (Table 1; Fig. 6). The mean $\delta^{13} \mathrm{C}$ values are $-9.6 \%$ and $-9.2 \%$ for ART and HOR, respectively.

Flowstones are centimetric coatings (up to $6 \mathrm{~cm}$ thick) covering cave walls and irregular bedrock morphologies with mammillary shape in surface (Fig. 7b). The internal laminae are occasionally merged in microstratigraphic units 
Fig. 5 a Open framework of boxwork blades consisting of calcite (red dyed) and dolomite (white). Crossed polars. b Elongated columnar calcite fabric of a stalagmite (crossed polars) (ID\#16, Table 1). c Feathered columnar fabric in the nucleus of a spherulite (botryoid) (crossed polars) (ID\#37, Table 1). d Elongated columnar fabric of the laminated coating of a spherulitic growth (botryoid) (crossed polars) (ID\#41, Table 1). e Fan ray fabric made of aragonite needles (parallel polars) (ID\#57, Table 1). f Rhombohedral calcite spar (parallel polars) (ID\#45, Table 1)
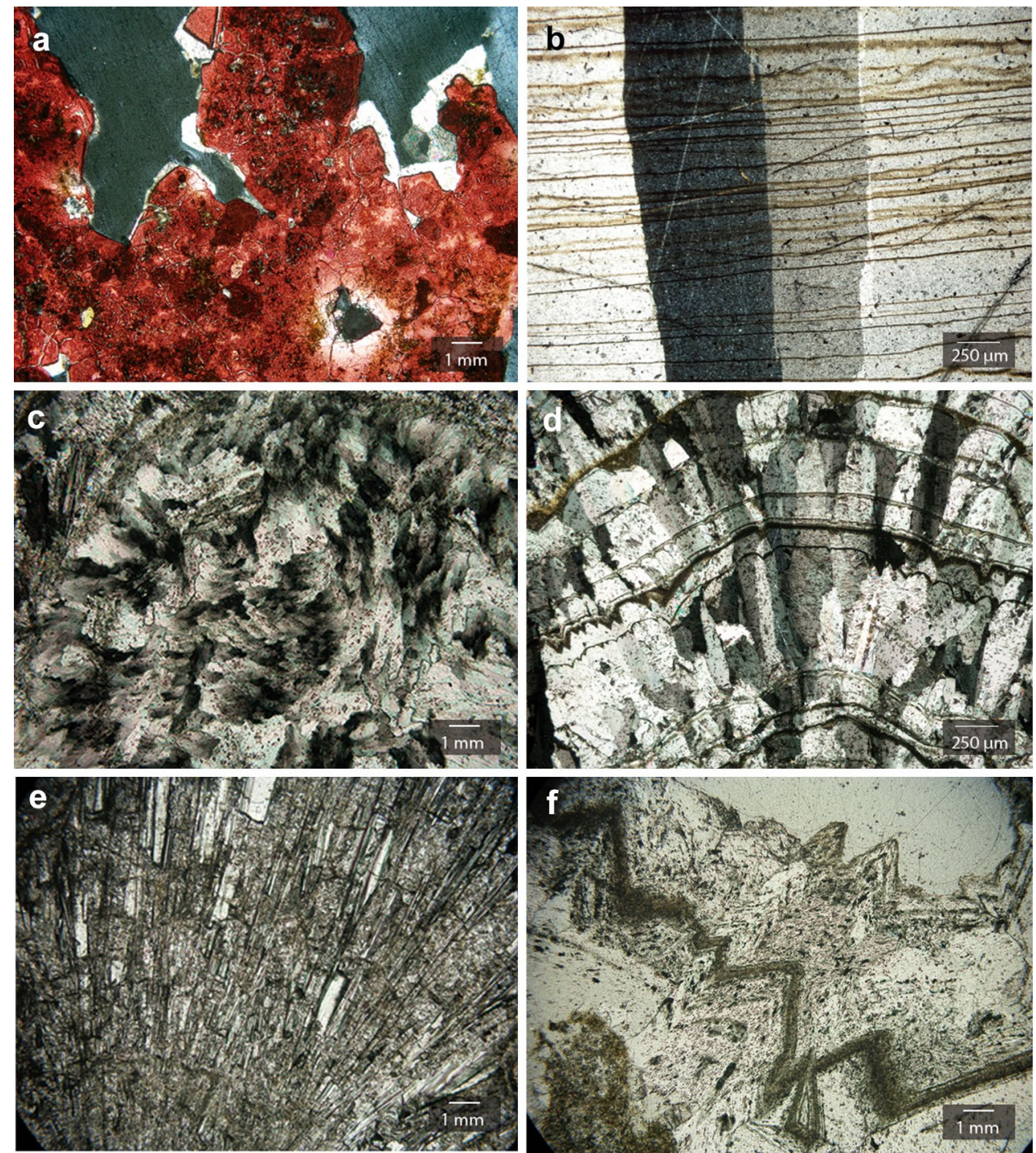

separated by unconformities. Coatings are made of calcite and high-magnesium calcite, displaying columnar (short, elongated and microcrystalline) and mosaic fabrics. Sparse dolomite has been also identified. The mean $\delta^{18} \mathrm{O}$ value is $-7.5 \%$, ranging from -7.1 to $-7.9 \%$ (Table 1 ; Fig. 6). The mean $\delta^{13} \mathrm{C}$ value is $-9.2 \%$, ranging from -7.9 to $-10.1 \%$. The age of one flowstone sample is $639 \pm 160 \mathrm{ka}$ (Tables 1 and 2).

The presence of other cave precipitates is also significant in Ejulve cave. Botryoidal deposits, acicular crystals and carbonate spars are very common and distributed throughout the cave (Fig. 3). Botryoidal deposits (coralloid or popcorn) are commonly centimetric in size, globular precipitates on the bedrock and sometimes on pendants, that appear in chambers and passages in the mid-to-upper sections of the cave (Figs. 4e, 7c-e). Botryoids are principally made of calcite and high-magnesium calcite (Table 1), with minor dolomite and show nucleus of columnar feathered fabric (Fig. 5c) surrounded by laminae of alternate micrite and columnar elongated fabrics (Fig. 5d). The botryoidal deposits of Ejulve cave exhibit mean $\delta^{18} \mathrm{O}$ values of $-7.0 \%$, ranging from -6.4 to $-7.8 \%$. The average $\delta^{13} \mathrm{C}$ value is $-8.5 \%$, ranging from -7.4 to $-9.7 \%$ (Table 1; Fig. 6). The ages of three botryoidal speleothems are $449 \pm 17.5 \mathrm{ka}$, $238.2 \pm 1.9 \mathrm{ka}$ and $155.9 \pm 2.2 \mathrm{ka}$ (Tables 1 and 2).

Acicular crystals (crystalline needles) are millimetric in size and grow on the bedrock but also on botryoidal deposits (Fig. 7f, g). They are mostly made of aragonite, although calcite, high-magnesium calcite and dolomite have been identified as minor components (Table 1). Microfabric of grouped needles is made of fans (rays and acicular) (Fig. 5e).

Carbonate spars are present as crystals, millimetric-tocentimetric in size, with rhombohedral or nail-head developments that mainly grow on the bedrock or on collapsed 


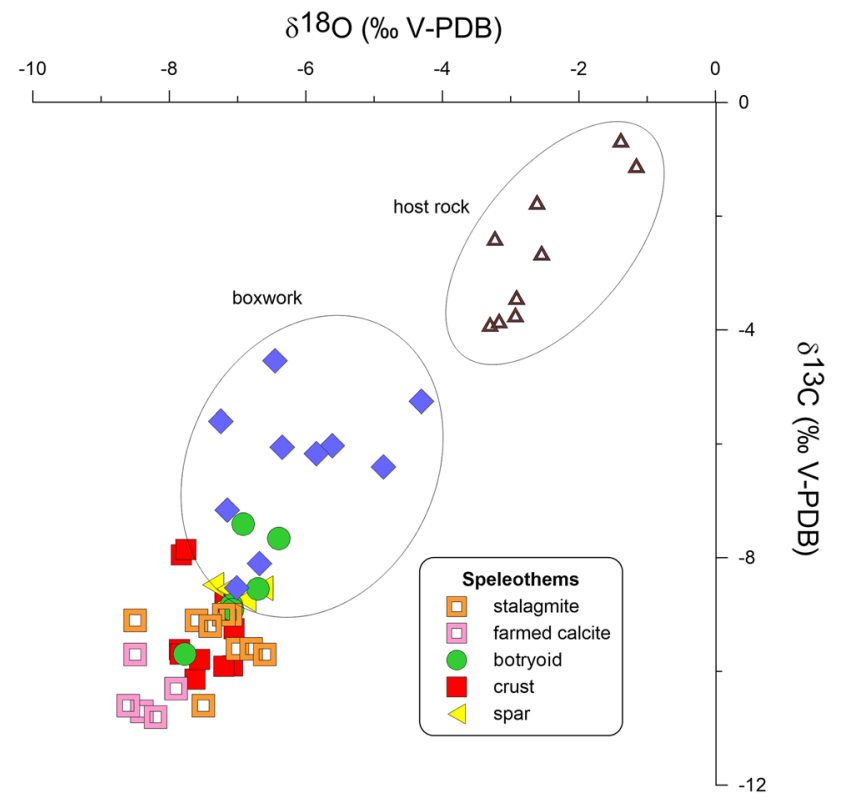

Fig. 6 Stable isotope composition of meteoric speleothems (mainly calcite and high-Mg calcite), boxwork blades (calcite and dolomite) and dolomite bedrock

breccias, and usually are linked to botryoids (Fig. 7h). They are common in the floors of the mid-to-lower sectors of the cave. Although the spars are mostly composed of calcite, small amounts of dolomite have also been identified (Table 1). Spar crystals are made of columnar elongated and columnar microcrystalline fabrics (Fig. 5f). The mean $\delta^{18} \mathrm{O}$ value is $-7.1 \%$, ranging from -6.6 to $-7.4 \%$ (Table 1 ; Fig. 6). The mean $\delta^{13} \mathrm{C}$ value is $-8.7 \%$, with $-8.5 \%$ o maximum and $-8.9 \%$ minimum values. The ages of two carbonate spar samples are 551.1 $\pm 77 \mathrm{ka}$ and $169.8 \pm 2 \mathrm{ka}$ (Tables 1 and 2). In addition, modern calcite precipitates were analyzed in this cave, which show mean $\delta^{18} \mathrm{O}$ value of $-8.3 \%$, ranging from -7.3 to $-9.3 \%$, and mean $\delta^{13} \mathrm{C}$ value of $-9.9 \%$, ranging from -7.2 to $-11.5 \%$ (PérezMejías et al. 2018).

\section{Discussion}

\subsection{Speleogenesis of Ejulve cave}

\subsubsection{Cave morphology}

Correct identification of morphological features is key to assess the origin of caves (Palmer 2011). The maze network of Ejulve cave follows an angular grid (Fig. 3), and it is difficult to assign this pattern type to a specific karstic environment. Angular patterns controlled by joints and faults are common in unconfined meteoric water caves (Ford and
Williams 2007). On the other hand, reticulate mazes of small passages related to joints have also been identified in caves related to confined circulation and basal injection of meteoric waters (Ford and Williams 2007). Finally, maze patterns are also common in hypogene cave systems, related to ascending flows (Bakalowicz et al. 1987; Palmer 1991; Klimchouk 2009; Dublyansky 2013).

Cave solutional features (vertical ceiling tubes, ceiling cupolas, pendants and cusps, spongework and rills) (Fig. 4) identified in Ejulve cave might have formed under epigene conditions, although they are very common in hypogenic hydrothermal caves. Rising flow under confined conditions could be responsible for the development of ceiling rising channels with associated chains of cupolas (Klimchouk 2009; Dublyansky 2013). Bedrock partitions including ceiling pendants and cusps could develop by either enlargement of adjacent cavities by water convection or/and condensation corrosion in more recent subaerial conditions (Dublyansky 2013). Regarding the smaller-scale morphological features, such as spongework (Palmer 2011; Dublyansky 2013) and bubble trails (Audra et al. 2002; Forti et al. 2002; Gázquez et al. 2015), they normally occur in a subaqueous setting, whereas rills features (Palmer 1991) form under subaerial conditions. In addition, dissolution morphologies (e.g. elliptic passage cross-sections and scallops) related to phreatic and vadose water flow, commonly found in caves of epigenic origin, are absent in Ejulve cave. Notably, significant isotope alteration of the dolomite host rock related to circulation of thermal water (Dublyansky 2012, 2013) is not recognized in Ejulve cave.

Both the pattern of the cave and the solutional features suggest that the initial formation stages of Ejulve cave might have been controlled by ascending thermal water under confined and/or unconfined conditions. Although this hypothesis is not conclusively supported, the presence of modern regional thermal springs reinforce this model (Bakalowicz et al. 1987; Ford and Williams 2007; Dublyansky 2013). Low-temperature hydrothermal anomalies have been reported by Sánchez et al. (2004) at Virgen de Ariño $\left(22.7^{\circ} \mathrm{C}\right)$ and Segura de los Baños $\left(24^{\circ} \mathrm{C}\right)$ spa resorts, located $29 \mathrm{~km}$ and $38 \mathrm{~km}$ from Ejulve cave, respectively (Fig. 1b, c). Virgen de Ariño water is $\mathrm{SO}_{4}-\mathrm{HCO}_{3}-\mathrm{Ca}$ type, while Segura de los Baños is $\mathrm{HCO}_{3}-\mathrm{Ca}$ type (data from http://www.chebro.es).

Current geothermal flow in the southeastern sector of Iberian Range derives from infiltrated meteoric water and emerges driven by hydraulic gradients. The fast water circulation occurs through high-permeability vertical structures that affect mainly hydrostratigraphic favorable units. These units can contain water and other fluids with the potential for thermal fluid flow, such as Triassic-Jurassic dolomite breccias and cellular dolostones (Sánchez et al. 2004). Meteoric infiltrated water would increase its temperature due to the 
Fig. 7 Epigenic cave deposits identified in Ejulve cave. Stalagmites, stalactites, soda-straws and gours (a), flowstones (b), botryoidal deposits $(\mathbf{c}, \mathbf{d}, \mathbf{e})$, crystalline acicules formed mostly by high-Mg calcite and aragonite (f, $\mathbf{g})$ and spar (h)
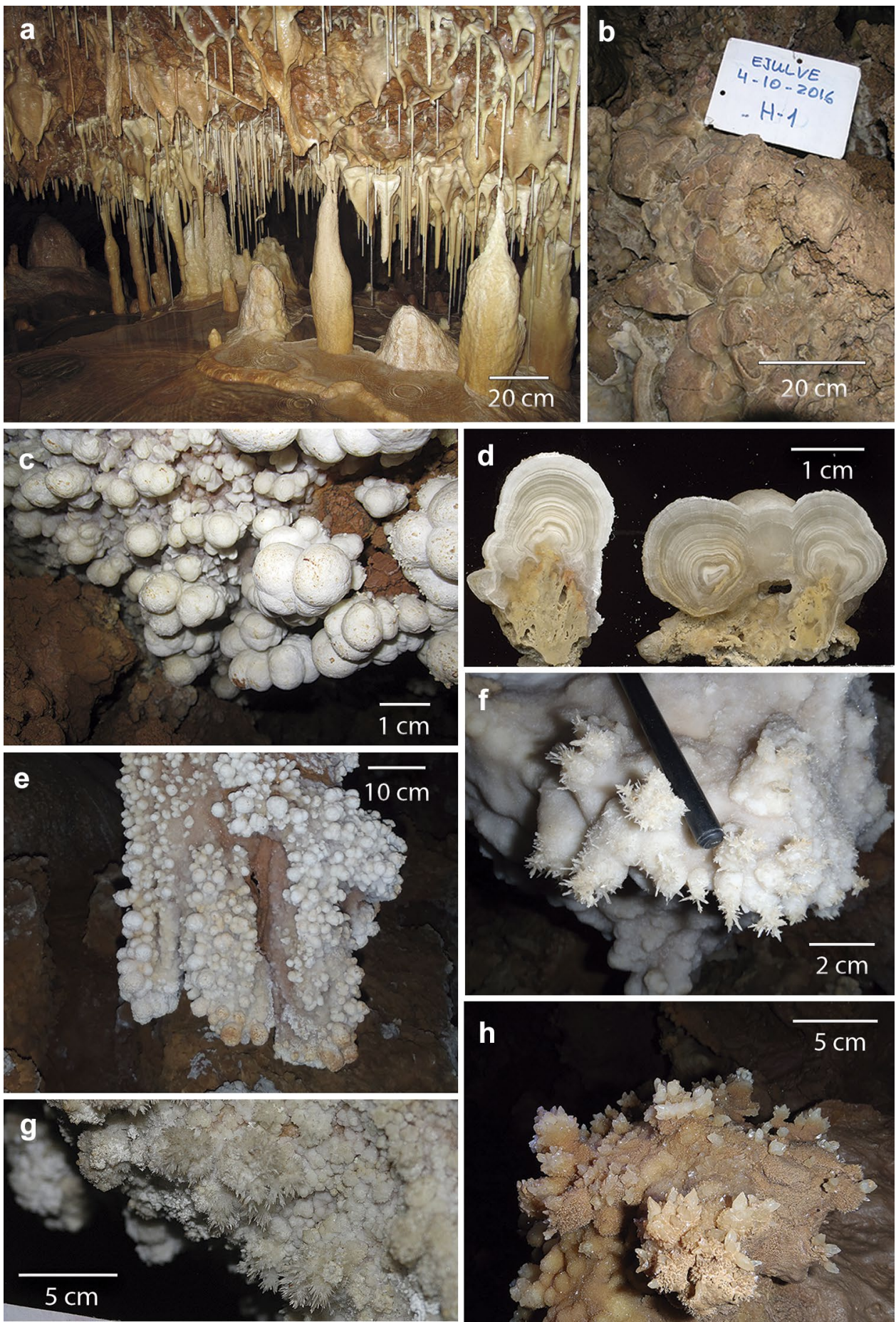

crustal geothermal gradient (Sánchez et al. 2004). Consequently, a meteoric flow regime (Klimchouk 2017) could be suggested to explain the low-temperature regional thermalism. Ascending water reaching the surface is also supported by the occurrence of travertine mounds (Sierra 2016) deposited along fissures (Ford and Pedley 1996), related to active faults in the vicinities of Ejulve cave (Sierra 2016).
Cave formation occurred before the final phase of the development of the Main Erosive Surface (Peña et al. 1984; Gutiérrez and Peña 1994). The current position of the cave near the topographic surface clearly indicates intensive denudation processes related to the development of this planation surface. 
Table $2{ }^{230}$ Th dating results of some meteoric carbonate precipitates

\begin{tabular}{lcccccccc}
\hline $\begin{array}{l}\text { Sample } \\
\text { number }\end{array}$ & ${ }^{238} \mathrm{U}(\mathrm{ppb})$ & ${ }^{232} \mathrm{Th}(\mathrm{ppt})$ & $\begin{array}{l}{ }^{230} \mathrm{Th} /{ }^{232} \mathrm{Th} \\
\left(\text { atomic } \times 10^{-6}\right)\end{array}$ & $\begin{array}{l}\delta^{234} \mathrm{U}^{\mathrm{a}}\left(\mathrm{meas}-{ }^{230} \mathrm{Th} /{ }^{238} \mathrm{U}\right. \\
\text { ured) }\end{array}$ & $\begin{array}{l}{ }^{230} \mathrm{Th} \text { age (year) } \\
\text { (uncorrected) }\end{array}$ & $\begin{array}{l}\delta^{234} \mathrm{U}_{\mathrm{Initial}}^{\mathrm{b}} \\
(\text { cor- } \\
\text { rected) }\end{array}$ & $\begin{array}{l}{ }^{230} \mathrm{Th} \text { age }(\mathrm{year} \\
\mathrm{BP}){ }^{\mathrm{c}}(\mathrm{corrected})\end{array}$ \\
\hline $\mathrm{H} 2$ & $63.8 \pm 0.0$ & $6745 \pm 135$ & $135 \pm 3$ & $74.1 \pm 1.4$ & $0.8659 \pm 0.0020$ & $172609 \pm 1136$ & $120 \pm 2$ & $169761 \pm 2258$ \\
$\mathrm{H} 4$ & $56.8 \pm 0.0$ & $294 \pm 6$ & $3278 \pm 70$ & $22.8 \pm 1.4$ & $1.0295 \pm 0.0029$ & $639314 \pm 161162$ & $138 \pm 81$ & $639084 \pm 160696$ \\
H5 & $38.1 \pm 0.0$ & $3037 \pm 61$ & $211 \pm 4$ & $18.4 \pm 1.6$ & $1.0195 \pm 0.0038$ & $553323 \pm 78417$ & $87 \pm 22$ & $551089 \pm 76602$ \\
H9 & $70.8 \pm 0.1$ & $18983 \pm 380$ & $64 \pm 1$ & $37.2 \pm 1.2$ & $1.0356 \pm 0.0023$ & $456165 \pm 17809$ & $132 \pm 8$ & $448985 \pm 17453$ \\
EJM-15 & $92.0 \pm 0.1$ & $140 \pm 3$ & $10151 \pm 228$ & $45.8 \pm 1.1$ & $0.9391 \pm 0.0018$ & $238288 \pm 1949$ & $90 \pm 2$ & $238181 \pm 1948$ \\
EJM-18 & $47.9 \pm 0.0$ & $5740 \pm 115$ & $131 \pm 3$ & $206.4 \pm 1.4$ & $0.9558 \pm 0.0032$ & $158643 \pm 1220$ & $320 \pm 3$ & $155904 \pm 2236$ \\
\hline
\end{tabular}

Sample names are indicated in Table 1

${ }^{230} \mathrm{Th}$ dating results. The error is $2 \sigma$. Sample number are referred to $\mathrm{mm}$ from base

Corrected ${ }^{230} \mathrm{Th}$ ages assume the initial ${ }^{230} \mathrm{Th} /{ }^{232} \mathrm{Th}$ atomic ratio of $4.4 \pm 2.2 \times 10^{-6}$. Those are the values for a material at secular equilibrium, with the bulk earth ${ }^{232} \mathrm{Th} /{ }^{238} \mathrm{U}$ value of 3.8 . The errors are arbitrarily assumed to be $50 \%$

${ }^{\mathrm{a}} \delta^{234} \mathrm{U}=\left(\left[{ }^{234} \mathrm{U} /{ }^{238} \mathrm{U}\right]_{\text {activity }}-1\right) \times 1000$

${ }^{\mathrm{b}} \delta^{234} \mathrm{U}_{\text {initial }}$ was calculated based on ${ }^{230} \mathrm{Th}$ age $(\mathrm{T})$, i.e., $\delta^{234} \mathrm{U}_{\text {initial }}=\delta^{234} \mathrm{U}_{\text {measured }} \times \mathrm{e}^{\lambda 234 \times \mathrm{T}}$

cB.P. stands for "Before Present" where the "Present" is defined as the year 1950 A.D.

\subsubsection{Boxwork}

The origin and the isotopic composition of boxwork can contribute to the understanding of the early stages of Ejulve cave formation. The blades forming the boxwork precipitated in discontinuities and joints of the dolomitic bedrock. The isotopic composition shows higher mean values of $\delta^{18} \mathrm{O}$ $(-6.2 \% o)$ and $\delta^{13} \mathrm{C}(-6.4 \% o)$ than other speleothems in Ejulve, but lower than dolomite host rock (mean value $\delta^{18} \mathrm{O}$ of $-2.6 \%$ and $\delta^{13} \mathrm{C}$ of $-2.6 \%$ ) (Fig. 6). These isotopic values correspond to the samples that had significant amounts of dolomite (Table 1), a mineral always with more positive values in $\delta^{18} \mathrm{O}$ than calcite (O'Neil and Epstein 1966). Therefore, dolomite may be responsible, at least partially, of the higher $\delta^{18} \mathrm{O}$ values of boxwork. Besides, comparison between the isotopic composition of blades from Ejulve cave and hydrothermal carbonates from other caves allows discarding the substantial role of high-temperature hydrothermalism in the precipitation of these carbonate blades (Bakalowicz et al. 1987; Orvošová et al. 2004; Spötl et al. 2009; Gradziński et al. 2011; Gázquez et al. 2018). The presence of detrital minerals, such as kaolinite, permits not to exclude a detrital origin coming from the dolomite host rock for some of the dolomite detected in the boxwork. The petrography does not offer any conclusive features.

\subsubsection{Carbonate precipitates}

Ejulve cave hosts a wide variety of carbonate speleothems, but lacks autochthonous or allochthonous fluvial deposits. In contrast, collapse breccias are frequent. Stalagmites ranging in age from MIS 8 to MIS 1 record the infiltration of meteoric water under epigenic conditions (Moreno et al. 2017; Pérez-Mejías et al. 2017).

Other precipitates such as botryoidal calcite (coralloids) are very common in this cave, as are aragonite and calcite spars (Fig. 7). These carbonates appear frequently in epigenic subaerial and subaqueous karstic environments (e.g. White 1988; Ford and Williams 2007). Specifically, Caddeo et al. (2015) explains the formation of coralloids as the result of degassing, evaporation and diffusion, and Vanghi et al. (2017) proposed that hydroaerosols produced by dripping water and evaporation played a key role in their formation. Coralloids also occur in shallow hydrothermal karst environments formed from saturated water vapor in subaerial environments and from ascending warm water saturated with respect to calcite in low hydrodynamic subaqueous conditions (Bakalowicz et al. 1987; Audra et al. 2002; Gradziński et al. 2011; Leél-Őssy et al. 2011; Dublyansky 2012).

The stable isotope composition of botryoidal deposits and spars (Fig. 6) which only contain insignificant amount of dolomite, is useful to distinguish between the epigenic and hydrothermal origin (Ford and Williams 2007). Mean $\delta^{18} \mathrm{O}$ values are $-7.0 \%$ (botryoids) and $-7.1 \%$ (spars) and mean $\delta^{13} \mathrm{C}$ values are $-8.5 \%$ (botryoids) and $-8.7 \%$ (spars). These values are very close to those obtained from calcite formed at relatively low temperature (flowstones show mean $\delta^{18} \mathrm{O}$ values of $-7.5 \%$ and $\delta^{13} \mathrm{C}$ values of $-9.2 \%$ ) and stalagmites formed during MIS 8 to MIS 7e (Pérez-Mejías et al. 2017), while the Holocene yielded similar mean values of $\delta^{18} \mathrm{O}=-7.2 \%$ and $\delta^{13} \mathrm{C}=-9.2 \%$ (Moreno et al. 2017). The small differences in $\delta^{18} \mathrm{O}$ between the various speleothem types can be explained by calcite precipitation under non-equilibrium conditions because of evaporation and/or enhanced $\mathrm{CO}_{2}$ degassing (Fairchild et al. 2006). A 
comparison with isotopic data of hydrothermal carbonates from systems worldwide (typically $\delta^{18} \mathrm{O}<-10 \%$ ) also suggests a non-hydrothermal origin of the Ejulve's precipitates (Bakalowicz et al. 1987; Orvošová et al. 2004; Spötl et al. 2009; Gradziński et al. 2011; Gázquez et al. 2018). Finally, it is remarkable that precipitation of flowstones, botryoids, and carbonate spar aggregates occurred from $639.1 \pm 160.7$ to $155.9 \pm 2.2 \mathrm{ka}$ (Table 2), simultaneously to the growth of some speleothems from MIS 8 to the present (Moreno et al. 2017; Pérez-Mejías et al. 2017, 2018) (Table 1). To sum up, oxygen isotopic composition of calcite deposits indicates an isotopic signal in agreement with meteoric waters with no influence of hydrothermal rising flow.

The presence of newly formed minerals (high-Mg calcite and aragonite, Table 1) which commonly precipitate from $\mathrm{Mg}$-rich solutions, as well as the most common fabrics (Fig. 5) of Ejulve speleothems suggest that they formed from waters enriched in $\mathrm{Mg}$ derived from the dolomite bedrock. A high $\mathrm{Mg} / \mathrm{Ca}$ ratio in the water favors the formation of aragonite (Gonzalez and Lohmann 1988). Aragonite precipitates in caves from $\mathrm{Mg}$-rich waters exhibit low supersaturation with respect to calcite (Spötl et al. 2016). Dolomite has been identified from XRD analyses in acicular, botryoid and spar precipitates but is not quantitatively relevant. In spite of the dolomite formation recorded in other caves (Alonso-Zarza and Martín-Pérez 2008; Jones 2010), its origin in Ejulve cave precipitates is still not clear.

\subsection{Geomorphic evolution of Ejulve cave}

Successive stages in the speleogenesis of Ejulve cave (Fig. 8) can be differentiated based on the morphochronological relationship between the cave and the regional landscape as well as the morphostratigraphic relationship between cave morphologies and cave deposits.

During the first stage, a network maze of passages and chambers and solutional features (boxwork, tubes with rising ceiling cupolas, pendants and cusps, spongework and microcorrosion features) probably formed during the main early speleogenetic phase. Although some morphologies (e.g. tubes with rising cupolas, pendants) could have
Fig. 8 Schematic evolution of Ejulve cave. Successive stages from ascending to descending water flow conditions in a meteoric circulation regime are differentiated and related to regional landscape evolution. Scale is not adjusted cave detail

landscape evolution

STAGE 1. Formation of cave: network maze and cave morphologies developed. Mio-Pliocene.
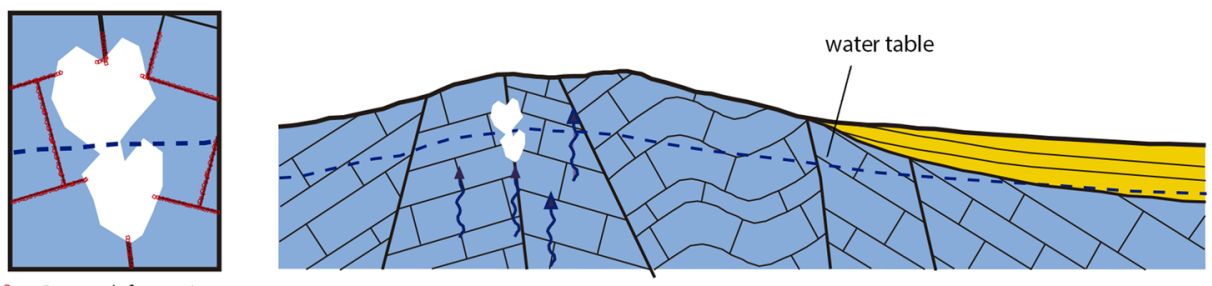

Boxwork formations

STAGE 2. Final phase of regional planation surface development and beginning of fluvial incision. Exhumation of cave. End of deep rising flow. Upper Pliocene-Lower Pleistocene.
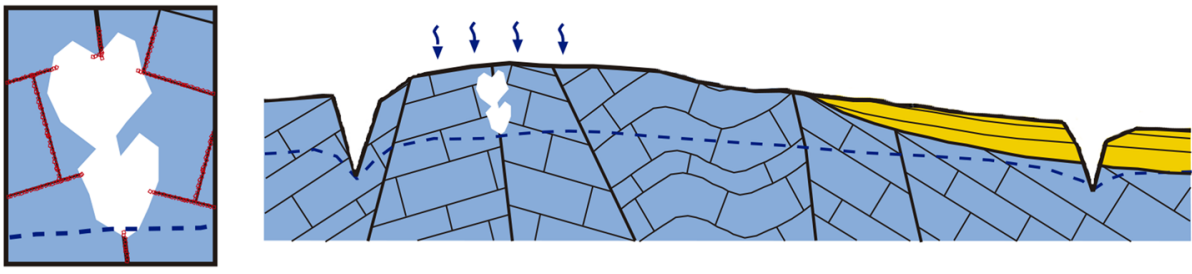

STAGE 3. Lowering of the base level related to fluvial downcutting. Growth of epigenic speleothems. Breakdown processes. Middle Pleistocene-Holocene ( $>650 \mathrm{ka}$ ).
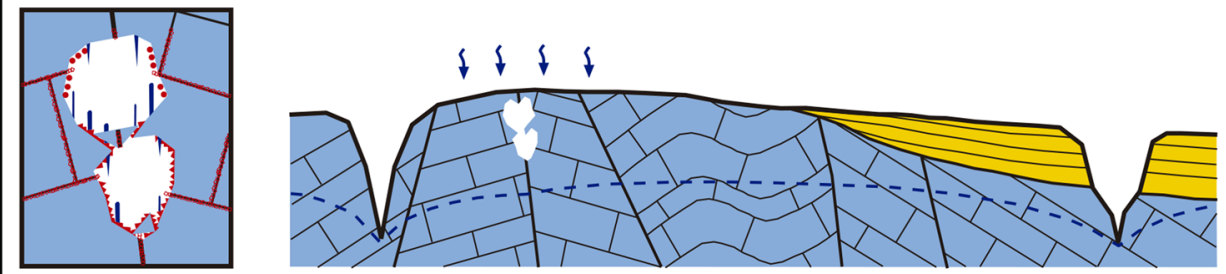

I Stalactites

I Stalagmites

Breakdown deposits

A Carbonate crusts and spars 
generated later under epigenic subaqueous conditions, the absence of fluvial deposits and dissolution morphologies related to vadose water flow in the cave (e.g. notches created by subterraneous water rivers), support the hypothesis of confined or semi-confined water flows, with water convection and condensation-corrosion processes probably involved. Likewise, this hypothesis would explain both the cave pattern and all the morphologies presented. Quaternary travertine mounds along faults near Ejulve cave (Sierra 2016) and modern warm springs (Sánchez et al. 2004) support the model of warm, upwelling waters forming caves in this region. To sum up, cave formation likely occurred in a low-temperature hydrothermal setting (Klimchouk 2017) simultaneous with the development of the Main Erosive Surface of the Iberian Range probably during Mio-Pliocene times (Peña et al. 1984; Gutiérrez and Peña 1994).

The second stage coincides with the final phase shaping the Main Erosive Surface of the Iberian Range (Upper Pliocene) (Peña et al. 1984). Lowering of the surface by denudation brought the cave to the current position close to the topographic surface. Subsequent landscape partition was driven by extensional tectonics (Simón et al. 2002; Gutiérrez et al. 2008) and fluvial incision related to regional uplifting started around $3 \mathrm{Ma}$ ago (Scotti et al. 2014; Giachetta et al. 2015), causing the onset of the lowering of the ground water table.

During the third stage, a regional Quaternary fluvial incision occurred, with a rate of $\sim 0.6 \mathrm{~mm} /$ year related to uplift proposed by Scotti et al. (2014). Under epigenic conditions, a wide variety of subaerial and subaqueous vadose speleothems (stalactites, stalagmites, curtains, flowstones, botryoidal deposits, spars and acicular crystals) precipitated in the cave. According to the age of the speleothems, this stage started before than $650 \mathrm{ka}$ and lasts until today (Moreno et al. 2017; Pérez-Mejías et al. 2017).

In summary, the origin of Ejulve cave likely occurred under deep confined, low-temperature hydrothermal conditions and speleothems precipitated under unconfined meteoric vadose conditions in later stages. This speleogenetic switch is common in caves formed in areas affected by uplift and denudation (Klimchouk 2013).

\section{Conclusions}

First insights into the speleogenesis of the Ejulve cave in the SE Iberian Range based on cave morphologies, cave deposits and the regional geological setting are provided.

We propose a three-stages speleogenetic model; this includes an earlier phase of ascending thermal flow of lowtemperature, although the evidences are not fully conclusive, and a final phase of descending meteoric waters. The stage of transition between them occurred before $650 \mathrm{ka}$ $\mathrm{BP}$ and was driven by denudation, tectonic uplift and fluvial incision.

Ascending water flow conducted to the development of a maze network pattern and gave rise to various cave solutional features such as tubes with rising ceiling cupolas, pendants and cusps, spongework and microcorrosion. Water convection and condensation-corrosion processes related to the water may have played a role in the hypothetical hypogene speleogenesis. The formation of the cave occurred probably before the Upper Pliocene.

During the more recent vadose stage (at least since $650 \mathrm{ka} \mathrm{BP}$ ), carbonate speleothems formed, including stalagmites, flowstones, botryoids, and spar. The stable isotope composition of these speleothems suggests crystallization under low-temperature conditions.

Acknowledgements We acknowledge the predoctoral research Grant from the Government of Aragón (B158/13) and CTM2013-48639-C22-R (OPERA) and CGL2016-77479-R (SPYRIT) projects for funding. Fernando Gázquez was financially supported by the "HIPATIA" research program of the University of Almeria. This is a contribution of "Procesos geoambientales y cambio global" group (E02_17R). We are also grateful to Belén Oliva-Urcía for her help in the fault measurements, Alfonso Meléndez for field examination of bedrock stratigraphy, Josep Elvira and Joaquin Perona for XRD analyses and stable isotope analyses, respectively. We also acknowledge the Ejulve Council for cave management, the use of Servicio General de Apoyo a la Investigación-SAI (University of Zaragoza), and the editor and two anonymous reviewers that improved the paper. This article is dedicated to the memory of Professor Carlos Sancho.

\section{References}

Allmendinger, R. W., Cardozo, N., \& Fisher, D. (2011). Structural geology algorithms: vectors and tensors. Cambridge: Cambridge University Press.

Alonso-Zarza, A. M., \& Martín-Pérez, A. (2008). Dolomite in caves: Recent dolomite formation in oxic, non-sulfate environments. Castañar Cave, Spain. Sedimentary Geology, 205, 160-164.

Álvaro, M., Capote, R., \& Vegas, R. (1979). Un modelo de evolución geotectónica para la Cadena Celtibérica. Acta Geológica Hispánica. Homenatge a Lluis Sole i Sabaris, T.14, 172-177.

Angosto, M. C., \& Latorre, J. L. (2000). Cavidades naturales del término municipal de Ejulve (Somontano turolense): datos espeleométricos y bioespeleológicos. Teruel, 1, 75-108.

Aranburu, A., Arriolabengoa, M., Iriarte, E., Giralt, S., Yusta, I., Martínez-Pillado, V., et al. (2015). Karst landscape evolution in the littoral area of the Bay of Biscay (north Iberian Peninsula). Quaternary International, 364, 217-230.

Audra, P., Bigot, J.-Y., \& Mocochain, L. (2002). Hypogenic caves in Provence (France). Specific features and sediments. Acta Carsologica, 31, 33-50.

Bakalowicz, M. J., Ford, D. C., Miller, T. E., Palmer, A. N., \& Palmer, M. V. (1987). Thermal genesis of dissolution caves in the Black Hills, South Dakota. Geological Society of America Bulletin, 99, 729-738.

Ballesteros, D., Jiménez-Sánchez, M., Giralt, S., García-Sansegundo, J., \& Meléndez-Asensio, M. (2015). A multi-method approach for 
speleogenetic research on alpine karst caves. Torca La Texa shaft, Picos de Europa (Spain). Geomorphology, 247, 35-54.

Bartolomé, M., Sancho, C., Moreno, A., Oliva-Urcia, B., Belmonte, A., Bastida, J., et al. (2015). Upper Pleistocene interstratal pipingcave speleogenesis: The Seso Cave System (Central Pyrenees, Northern Spain). Geomorphology, 228, 335-344.

Caddeo, G. A., Railsback, L. B., De Waele, J., \& Frau, F. (2015). Stable isotope data as constraints on models for the origin of coralloid and massive speleothems: The interplay of substrate, water supply, degassing, and evaporation. Sedimentary Geology, 318, 130-141.

Calaforra, J., \& Berrocal, J.A. (2008). El Karst de Andalucía, Geoespeleología, Bioespeleología y Presencia Humana. Consejería de Medio Ambiente dela Junta de Andalucía. Sevilla.

Canérot, J. (1982). Ibérica central-Maestrazgo. In A. García (Ed.), El Cretácico de España (pp. 273-344). Madrid: Universidad Complutense de Madrid.

Cardozo, N., \& Allmendinger, R. (2013). Spherical projections with OSXStereonet. Computers \& Geosciences, 51, 193-205.

Castellano, L., Fernández, M., García, F., Gil, L., Gordillo, J., Mallén, D., Porcel, E., Royo, J. (2015). Cavidades de Teruel. 25 cuevas y simas de la provincia. Centro de Estudios Espeleológicos Turolenses, Zaragoza.

Cheng, H., Lawrence Edwards, R., Shen, C.-C., Polyak, V. J., Asmerom, Y., Woodhead, J., et al. (2013). Improvements in ${ }^{230} \mathrm{Th}$ dating, ${ }^{230} \mathrm{Th}$ and ${ }^{234} \mathrm{U}$ half-life values, and U-Th isotopic measurements by multi-collector inductively coupled plasma mass spectrometry. Earth and Planetary Science Letters, 371-372, 82-91.

Dodero, A., Bartolomé, M., Sancho, C., Moreno, A., Oliva-Urcia, B., Meléndez, A., et al. (2015). Incisión fluvial a partir del conjunto multinivel de cuevas de La Galiana (Parque Natural del río Lobos, Soria). Geogaceta, 58, 111-114.

Dublyansky, Y. (2012). Hydrothermal caves. Encyclopedia of caves. New York: Elsevier.

Dublyansky, Y. (2013). Karstification of geothermal waters. In J. Schroder \& A. Frumkin (Eds.), Treatise of Geomorphology (pp. 57-71). San Diego: Academic Press.

Durán, J. J., Grün, R., \& Ford, D. C. (1993). Dataciones geocronológicas absolutas (métodos ESR y Series de Uranio) en la Cueva de Nerja y su entorno. Implicaciones evolutivas, paleoclimáticas y neosismotectónicas. Trabajos sobre la Cueva de Nerja, 3, 233-248.

Fairchild, I., Smith, C., Baker, A., Fuller, L., Spötl, C., Mattey, D., et al. (2006). Modification and preservation of environmental signals in speleothems. Earth-Science Reviews, 75, 105-153.

Ford, D. C., \& Williams, P. (2007). Karst hydrogeology and geomorphology. New York: Wiley.

Ford, T., \& Pedley, H. (1996). A review of tufa and travertine deposits of the world. Earth-Science Reviews, 41, 117-175.

Forti, P., Galdenzi, S., \& Sarbu, S. M. (2002). The hypogenic caves: a powerful tool for the study of seeps and their environmental effects. Continental Shelf Research, 22, 2373-2386.

Frisia, S. (2015). Microstratigraphic logging of calcite fabrics in speleothems as tool for palaeoclimate studies. International Journal of Speleology, 44, 1-16.

Frisia, S., \& Borsato, A. (2010). Karst. In A. M. Alonso-Zarza \& L. H. Tanner (Eds.), Carbonates in continental settings. Facies, environments and processes. Developments in sedimentology (Vol. 61, pp. 269-318). Amsterdam: Elsevier.

Frisia, S., Borsato, A., Fairchild, I. J., \& McDermott, F. (2000). Calcite fabrics, growth mechanisms, and environments of formation in speleothems from the Italian Alps and Southwestern Ireland. Journal of Sedimentary Research, 70, 1183-1196.

Gázquez, F., Calaforra, J.-M., Forti, P., De Waele, J., \& Sanna, L. (2015). The role of condensation in the evolution of dissolutional forms in gypsum caves: Study case in the karst of Sorbas (SE Spain). Geomorphology, 229, 100-111.
Gázquez, F., Calaforra, J.M., Ros, A., Llamusí, J., Sánchez, J. (2016). Hypogenic morphologies and speleothems in caves in the Murcia Region, southeastern Spain. In Chavez, T., Reehling, P. (Eds.), Proceedings of deepkarst 2016: Origins, resources, and management of hypogene karst. National cave and karst research institute, Carlsbad, NM, pp. 53-60.

Gázquez, F., Calaforra, J. M., Rodríguez-Estrella, T., Ros, A., Llamusí, J. L., \& Sánchez, J. (2017). Evidence for regional hypogene speleogenesis in Murcia (SE Spain). In A. Klimchouk, A. Palmer, J. De Waele, A. S. Auler, \& P. Audra (Eds.), Hypogene karst regions and caves of the world (pp. 85-97). New York: Springer.

Gázquez, F., Columbu, A., De Waele, J., Breitenbach, S., Huang, C., Shen, C., et al. (2018). Quantification of paleo-aquifer changes using clumped isotopes in subaqueous carbonate speleothems. Chemical Geology, 493, 246-257.

Giachetta, E., Molin, P., Scotti, V. N., \& Faccenna, C. (2015). PlioQuaternary uplift of the Iberian Chain (central-eastern Spain) from landscape evolution experiments and river profile modeling. Geomorphology, 246, 48-67.

Ginés, J., Fornós, J. J., Gràcia, F., Merino, A., Onac, B. P., \& Ginés, A. (2017). Hypogene imprints in coastal karst caves from Mallorca Island (Western Mediterranean): Morphological features and speleogenetic approach. In A. Klimchouk, N. A. Palmer, J. De Waele, S. A. Auler, \& P. Audra (Eds.), Hypogene karst regions and caves of the world (pp. 99-112). Cham: Springer International Publishing.

Gisbert, M., \& Carvajal, S. (1993). Cavidades de Aragón. Zaragoza: Federación Aragonesa de Espeleología.

Gonzalez, L. A., \& Lohmann, K. C. (1988). Controls on mineralogy and composition of spelean carbonates. In N. P. James \& P. W. Choquette (Eds.), Paleokarst (pp. 81-101). New York: Springer-Verlag.

Gràcia, F., Ginés, J., Pons, G.X., Ginard, A., Vicens, D. (Eds.) (2011). El carst: Patrimoni natural de les Illes Balears, Endins, 35/Mon. Soc. Hist. Nat. Balears, 17. ed. Palma de Mallorca.

Gradziński, M., Hercman, H., Kicińska, D., Pura, D., \& Urban, J. (2011). Ascending speleogenesis of Sokola Hill: A step towards a speleogenetic model of the Polish Jura. Acta Geologica Polonica, 61, 341-365.

Guimerà, J. (1988). Estudi structural de l'enllaç entre la Serralada Ibérica i la Serralada Costanera Catalana (Tesis doctoral). Universidad de Zaragoza.

Gutiérrez, F., Gutiérrez, M., Gracia, F. J., McCalpin, J. P., Lucha, P., \& Guerrero, J. (2008). Plio-quaternary extensional seismotectonics and drainage network development in the central sector of the Iberian Chain (NE Spain). Geomorphology, 102, 21-42.

Gutiérrez, M., \& Peña, J. L. (1994). Cordillera Ibérica. In M. Gutiérrez (Ed.), Geomorfología de España (pp. 251-286). Madrid: Editorial Rueda.

Jones, B. (2010). The preferential association of dolomite with microbes in stalactites from Cayman Brac, British West Indies. Sedimentary Geology, 226, 94-109.

Klimchouk, A. (2009). Morphogenesis of hypogenic caves. Geomorphology, 106, 100-117.

Klimchouk, A. (2013). Hypogene Speleogenesis. In J. Schroder \& A. Frumkin (Eds.), Treatise on geomorphology (pp. 220-240). San Diego: Academic Press.

Klimchouk, A. (2017). Types and settings of hypogene karst. In A. Klimchouk, A. N. Palmer, J. De Waele, A. S. Auler, \& P. H. Audra (Eds.), Hypogene karst regions and caves of the world (pp. 1-39). New York: Springer.

Klimchouk, A., Ford, D., Palmer, A., \& Dreybrodt, W. (Eds.). (2000). Speleogenesis. Evolution of karst aquifers. Huntsville: National Speleological Society. 
Leél-Ôssy, S., Szanyi, G., \& Surányi, G. (2011). Minerals and speleothems of the József-hegy Cave (Budapest, Hungary). International Journal of Speleology, 40, 191-203.

Liesa, C. (1998). Estructura y cinemática del arco de cabalgamientos Portalrubio-Vandellós en el sector de Castellote (Teruel). Grupo de Estudios Masinos, 18, 9-37.

Moreno, A., Pérez-Mejías, C., Bartolomé, M., Sancho, C., Cacho, I., Stoll, H., et al. (2017). New speleothem data from Molinos and Ejulve caves reveal Holocene hydrological variability in northeast Iberia. Quaternary Research, 88, 223-233.

O'Neil, J. R., \& Epstein, S. (1966). Oxygen isotope fractionation in the system dolomite-calcite-carbon dioxide. Science, 152, 198-201.

Ortega, A. I., Benito-Calvo, A., Pérez-González, A., Martín-Merino, M. A., Pérez-Martínez, R., Parés, J. M., et al. (2013). Evolution of multilevel caves in the Sierra de Atapuerca (Burgos, Spain) and its relation to human occupation. Geomorphology, 196, 122-137.

Orvošová, M., Hurai, V., Simon, K., \& Wiegerová, V. (2004). Fluid inclusion and stable isotopic evidence for early hydrothermal karstification in vadose caves of the Nízke Tatry Mountains (Western Carpathians). Geologica Carpathica, 55, 421-429.

Pailhé, P. (1984). La Chaîne Ibérique Orientale. Étude géomorphologique (Thèse de Doctorat d'Etat). Université Bordeaux III.

Palmer, A. (1991). Origin and morphology of limestone caves. Geological Society of America Bulletin, 103(1), 1-21.

Palmer, A. N. (2011). Distinction between epigenic and hypogenic maze caves. Geomorphology, 134, 9-22.

Peña, J.L., Gutiérre Elorza, M., Jesus Ibáñez Marcellan, M., Victoria Lozano Tena, M., Vidal, J., Sánchez Fabre, M., Luis Simón Gomez, J., Soriano, M., Miguel Yetano Ruiz, L. (1984). Geomorfología de la Provincia de Teruel. Instituto de Estudios Turolenses.

Pérez-Mejías, C., Moreno, A., Sancho, C., Bartolomé, M., Stoll, H., Cacho, I., et al. (2017). Abrupt climate changes during Termination III in Southern Europe. Proceedings of the National Academy of Sciences, 114, 10047-10052.

Pérez-Mejías, C., Moreno, A., Sancho, C., Bartolomé, M., Stoll, H., Osácar, M. C., et al. (2018). Transference of isotopic signal from rainfall to dripwaters and farmed calcite in Mediterranean semiarid karst. Geochimica et Cosmochimica Acta, 243, 66-98.
Sánchez, J. Á., Coloma López, P., \& Perez-Garcia, A. (2004). Evaluation of geothermal flow at the springs in Aragón (Spain), and its relation to geologic structure. Hydrogeology Journal, 12, 601-609.

Sancho, C., Arenas, C., Vázquez-Urbez, M., Pardo, G., Lozano, M. V., Peña-Monné, J. L., et al. (2015). Climatic implications of the Quaternary fluvial tufa record in the NE Iberian Peninsula over the last 500 ka. Quaternary Research, 84, 398-414.

Scotti, V. N., Molin, P., Faccenna, C., Soligo, M., \& Casas-Sainz, A. (2014). The influence of surface and tectonic processes on landscape evolution of the Iberian Chain (Spain): Quantitative geomorphological analysis and geochronology. Geomorphology, 206, 37-57.

Sierra, P. (2016). Superficies de erosión y evolución morfotectónica de un sector de la Cordillera Ibérica oriental (Trabajo Fin de Grado). Zaragoza: Universidad de Zaragoza.

Simón, J. L. (1984). Compresión y distensión alpinas en la Cadena Ibérica oriental. Teruel: Instituto de Estudios Turolenses.

Simón, J. L., Liesa, C. L., \& Arlegui, L. E. (2002). Alpine tectonics I. The Iberian Ranges. In W. Gibbons \& M. T. Moreno (Eds.), The geology of Spain (pp. 385-397). London: Geological Society.

Sopeña, A. (2004). Cordilleras Ibérica y Costero Catalana. In Vera, J.A. (Ed.), Geología de España (pp. 467-470). Madrid.

Spötl, C., Dublyansky, Y., Meyer, M., \& Mangini, A. (2009). Identifying low-temperature hydrothermal karst and palaeowaters using stable isotopes: A case study from an alpine cave, Entrische Kirche, Austria. International Journal of Earth Sciences, 98, 665-676.

Spötl, C., Fohlmeister, J., Cheng, H., \& Boch, R. (2016). Modern aragonite formation at near-freezing conditions in an alpine cave, Carnic Alps, Austria. Chemical Geology, 435, 60-70.

Vanghi, V., Frisia, S., \& Borsato, A. (2017). Genesis and microstratigraphy of calcite coralloids analysed by high resolution imaging and petrography. Sedimentary Geology, 359, 16-28.

White, W. (1988). Geomorphology and hydrology of karst terrains. Oxford: Oxford University Press. 